\title{
Kidney Cancer pT0 TNM Finding v6 and v7
}

National Cancer Institute

\section{Source}

National Cancer Institute. Kidney Cancer pTO TNM Finding v6 and v7. NCI Thesaurus.

Code C63561.

No evidence of primary tumor. (from AJCC 6th and 7th Eds.) 